Article

\title{
Nomadic, Informal and Mediatised Work Practices: Role of Professional Social Approval and Effects on Quality of Life at Work
}

\author{
Maëlle Périssé $^{1, *}$, Anne-Marie Vonthron ${ }^{1}$ and Émilie Vayre ${ }^{2}$ \\ 1 Parisian Laboratory of Social Psychology (LAPPS-TE2O), Psychology Department, University Paris Nanterre, \\ 92000 Nanterre, France; anne-marie.vonthron@parisnanterre.fr \\ 2 INSERM Unit U1296, Psychology Institute, Lumière University Lyon 2, 69008 Lyon, France; \\ emilie.vayre@univ-lyon2.fr \\ * Correspondence: maelle-perisse@hotmail.fr
}

check for

updates

Citation: Périssé, M.; Vonthron, A.-M.; Vayre, É. Nomadic, Informal and Mediatised Work Practices: Role of Professional Social Approval and Effects on Quality of Life at Work. Sustainability 2021, 13, 12878. https:/ / doi.org/10.3390/su132212878

Academic Editors: Subhas

Mukhopadhyay, Yoshiyasu Takefuji and Enrico Vezzetti

Received: 21 October 2021

Accepted: 15 November 2021

Published: 21 November 2021

Publisher's Note: MDPI stays neutral with regard to jurisdictional claims in published maps and institutional affiliations.

Copyright: (c) 2021 by the authors. Licensee MDPI, Basel, Switzerland. This article is an open access article distributed under the terms and conditions of the Creative Commons Attribution (CC BY) license (https:// creativecommons.org/licenses/by/ $4.0 /)$.

\begin{abstract}
Several studies have emphasised the effects of perceived social approval in employees' professional environment (colleagues and managers) on the implementation of remote and mediatised work practices and, more specifically, on their spatial, temporal and material characteristics. The use of information and communication technologies has been identified in the literature not only as affecting the levels felt by employees in terms of their relation to work (organisational commitment and recognition for work accomplished) but also in terms of work-life balance and health (stress and addictions). However, these studies are few in number when it comes to nomadic and informal work practices and rarely address perceived social approval in employees' professional entourage. We used an empirical study based on a questionnaire survey. The results indicate that employees favour smartphone and laptop use. The effects of perceived social approval in their professional entourage differ according to the technologies used. These uses also have an impact on commitment and recognition, but their effects on employees' perception of the effects of work life on "non-work" life and on addiction-related behaviours are more nuanced. These findings lead us to discuss the "right to disconnect" and the development of support and supervision schemes for nomadic, informal and mediatised work practices.
\end{abstract}

Keywords: nomadic work mediatised by ICTs; perceived social approval; relationship to work; work-home interaction; addiction

\section{Introduction}

The increasing use of technologies in the workplace has resulted in changes in the organisation of work activities, which are now performed in much more varied and changing locations and temporalities [1-3]. As a result, we observe a gradual disappearance of the landmarks usually associated with both work and non-work life [4]. In France, more than $70 \%$ of executives work outside their offices [5] in a variety of spaces (home, transportation, etc.) and outside regular working hours (evenings, weekends, etc.).

At the same time, French policies adopted in the last decade on the right of employees to telework, combined with notable changes in workspaces, reinforced the emergence of increasingly nomadic work practices enhanced by ICTs. Thus, legislation adopted in 2017 (the "Macron Ordinance") abolishes the need for contractualisation and recognises grey and occasional telework, thereby encouraging mediatised, remote and informal practices [6]. The development of the phenomenon both in France and internationally is such that some authors have even referred to the birth of a "nomadic work culture" [7]. The accentuation of these practices in the short and medium term is being further reinforced by the COVID19 pandemic, which has required accelerated expansion, on an unprecedented scale, of ICT-mediatised work "outside the walls" of companies. 
It has been identified in the literature that these new forms of remote work and their different characteristics alter the relationship between employees and the companies employing them [8]. Some studies report effects not only on the degree of organisational commitment felt by employees but also on recognition for their work [9]. In addition, they also present potential risks in terms of maintaining work-life balance and may increase work and internet addiction [10]. However, little research has specifically focused on nomadic, informal and mediatised work practices, which limits the possibilities of both characterising and defining them and assessing their impact and examining the factors that may encourage or inhibit them.

This paper investigates the effects of one psychosocial factor (i.e., perceived social approval) on the frequency of a variety of technologies uses (smartphone, laptop and tablet) within the context of nomadic, informal and mediatised work practices. It also questions the consequences of these frequencies of use in terms of the relationship to the organisation (i.e., organisational commitment and perceived recognition at work), work-life balance and specific health aspects (i.e., work addiction and internet addiction). We first discuss the scientific studies contained in the academic literature in this field before presenting the results of a survey conducted among French workers engaged in nomadic, informal and mediatised work practices. These results support the conclusions of previous studies on the impact of the use of ICTs in the context of remote and mediatised work practices and reaffirm the importance of developing procedures for supervising and regulating these technologies in relation to professional activities.

\section{Remote and Mediatised Work: Perceived Social Approval on the Part of the Professional Entourage and Quality of Life at Work}

The literature on remote and mediatised work is abundant and highlights the consequences of these practices on employees' relationship with their organisation, their work-life balance and their health. It also emphasises how perceptions of these practices affect their adoption and deployment.

2.1. Telework, Supplemental Work and "New Ways of Working": Similarities and Disparities with Nomadic, Informal and Mediatised Work Practices

Telework or "remote work" refers to a type of work organisation that may be divided into four main categories according to its characteristics [11,12]: the use of ICTs to carry out work tasks; the location of these practices in places other than the company (home, third places dedicated to work, such as co-working spaces or satellite offices, and non-dedicated places, such as restaurants or even public transport); the temporalities during which these practices are carried out (full-time, alternating or part-time and occasional); and finally whether these practices are contractualised or not.

For some authors, informal or non-contractualised telework, referred to as "grey telework," is more associated with the notion of "supplemental work," i.e., professional activities not included in standard working time [13], and even "spillover work" [14], which implies a disappearance of the boundaries between family, personal and professional life, with work activities being performed during times normally devoted to private life (weekends, holidays and evenings). These practices, in addition to telework, are part of the dynamics surrounding the "new ways of working" (NWW), which require employees to organise their work in a flexible manner by choosing their own workplaces, temporalities and tools [15].

The concept of the "nomadic worker" has been investigated in relation to mobile work. Mark and Su [16] defined "nomadic workers" as workers who travel to meet with clients or business associates, but more recent studies have identified differences between mobile and nomadic work, arguing that nomadic workers are distinguished not only by their desire and ability to move their workplace to different locations [17] but also by the fact that they must be able to maintain a nomadic lifestyle [18].

The nomadic, informal and mediatised work practices addressed in this study cover work practices similar to grey telework and those carried out by the nomadic workers 
mentioned above. The employees concerned usually perform their work tasks in places other than their home company by making use of technology. As a result, these noncontracted practices with the employer can be performed over a wide range of time periods, from several minutes to several hours, and at any time of the day. As such, they also include spillover and "supplemental" work practices.

\subsection{Social Approval towards Remote and Mediatised Work Practices}

Social approval can be defined as "the fact of valuing others as well as their judgments, and the display of behaviors appropriate for social interactions" [19] (p. 885). For Hebert and his colleagues [20], it refers to the tendency to seek positive responses from others regarding our behaviour, especially in the form of compliments or support.

Several studies addressing remote and mediatised work practices reveal the deleterious effects of these practices and of the physical distance they imply [21] on the organisational commitment of employees and on interactions between members of the organisation [22,23]. Within organisations, it has been identified that perceptions about these practices and their consequences at a professional level are likely to influence their implementation and their spatial, temporal or even material characteristics. For example, Scott et al. [20] reported that the implementation of remote work practices was supported by the way the employee's entourage (friends, neighbours and colleagues) perceived these practices.

Few studies have established a link between perceived social approval on the part of the employees' professional entourage and the adjustment of their remote and mediatised work practices. Some studies do, however, demonstrate that the adoption of telework depends in particular on the employees' desire to be more present to meet the needs of their families and friends [24,25]. Moreover, some other studies [26,27] specify that remote workers tend to develop specific behaviours in the context of their professional practices, such as the more frequent use of emails or telephone calls, in order to remain visible to their professional entourage.

Lastly, the question of perceived social approval of nomadic, informal and mediatised work practices can be studied through the prism of the acceptance of the technologies mobilised as part of these practices and their adoption in companies. Brown et al. [28] have shown that perception of the voluntary or involuntary adoption of technologies affects employees' attitudes towards them, including their uses.

\subsection{Remote and Mediatised Work and Quality of Life at Work: Impacts on Organisational Commitment and Perceived Recognition at Work, on Work-Life Balance and on Work, Internet and Technology Addictions}

In a 2018 study, de Vries and colleagues [23] observed an increase in employees' commitment to their organisation in the context of the mediatised remote work practices they conducted at home. This increase is notably a response to the offer of autonomy and flexibility included in this type of work practice and supported by the use of ICTs. The importance of autonomy as a factor of commitment to the company in the context of remote work is also demonstrated in earlier studies [25,29], underlining a higher level of commitment as soon as employees are given a choice of location or working time. However, other works provide more contrasting results, pointing out that remote work either has no impact on commitment [20] or tends to reduce it [30].

Several authors additionally note the importance of recognition at work as a motivating and engaging factor for employees [22,31]. The marks of that recognition are transmitted through interactions within the professional entourage [32]. According to several studies, the use of technologies in work activities tends to make communication and the sharing of information among employees easier and more efficient $[4,33]$.

However, it has been reported in the context of remote and mediatised work that employees experience higher levels of perceived isolation as a result of decreased personal interaction with other workers within their organisations [11,33-35]. While few studies have pointed out significant effects of remote and mediatised work on perceived work 
recognition, it has been acknowledged that receiving recognition in the context of these practices is considered valuable to employees and has an effect on their future within their organisation [36]. Furthermore, in a study on university researchers, Aczel et al. [9] reported that researchers lament a loss of both feedback and support from their institutions.

At the same time, some studies mention the presence of temporal and spatial flexibility in these situations, which facilitates the management of both family and professional responsibilities [37-39]. However, more recent work evokes the risks for this very same work-life balance, especially when work is performed at home, engendered by the use of technologies that imply quasi-permanent reachability [40-43]. Remote work practices are also linked to the development of spillover work [44]: in other words, the performance of work tasks outside temporalities defined as being devoted to work activities.

Finally, the use of technology in the workplace results in an extension and intensification of work that can make it difficult for workers to disengage from their activity and, consequently, be exposed to stress, psychological distress and anxiety, as well as work overload [45-47]. While some studies mention positive effects of mediatised and remote work, such as reduced sick leave, stress, noise and interruptions [48,49], favoured by temporal flexibility and reduced travel to the official workplace, other studies report that specific characteristics of mediatised remote work actually increased the occurrence of these risks.

More specifically, some studies show an increased risk that remote workers will develop addictions related to these practices $[10,50]$. Indeed, the frequent use of technologies required by these work situations, combined with the extension of work activities beyond usual work temporalities, favours the appearance of addictions to work, technologies and the internet $[3,51,52]$.

\subsection{Questions and Research Aims}

Studies on telework focus mainly on contractualised telework practices with the employer or on the uses of technologies in the workplace. As a result, the literature on nomadic, informal and mediatised work practices remains sparse, although these situations are more widespread than formal activities and are currently increasing [53-55].

Physical distance from the workplace and the work collective can make it more difficult to develop a sense of commitment to the organisation. Such distance can also impact the transmission of recognition on the part of colleagues, superiors and subordinates regarding the work performed by remote employees. Some studies have highlighted differences in the perception and approval of nomadic forms of work on the part of the employees entourage depending on the type of location where these activities are performed [42].

Moreover, the increased use of technologies in these situations and ease of access to work tasks anywhere at any time allow work to be carried out in a wide variety of time frames and locations, reinforcing the risks for maintaining the balance between private and professional life when work can be performed at home. Lastly, the absence of formal regulation of work temporalities may encourage the development or resurgence of addictions to both work and technologies.

The aim of our study is to understand the relationship between perceived social approval on the part of the workers' professional entourage, the uses of technologies mobilised in the context of these practices and the impact of these uses on both the employees' relationship with their organisation and their work-life balance and health. Our narrative is based on the following research model (see Figure 1). 


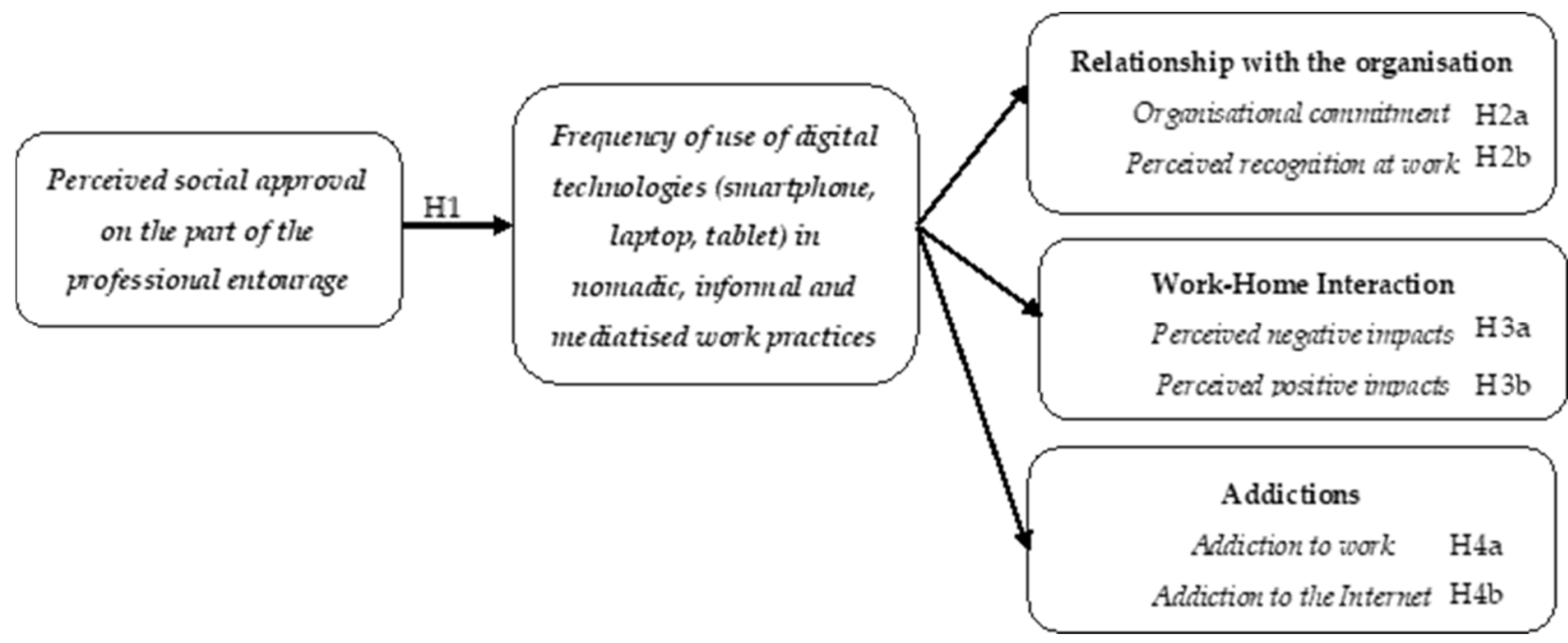

Figure 1. General research model of our study.

Hypothesis 1 (H1). The more workers perceive that their professional entourage approves their nomadic, informal and mediatised work, the more frequently they will use various technologies mobilised (smartphone/mobile phone, laptop and tablet) in the context of their professional practice.

Hypothesis 2a (H2a). The more these technologies are used by the employees, the more they will feel a strong commitment to their organisation.

Hypothesis $\mathbf{2 b}(\mathbf{H} \mathbf{2} \mathbf{b})$. The more they will perceive recognition at work on the part of their organisational environment.

Hypothesis 3a (H3a). The increase in the frequency of using technologies in the context of nomadic and informal work practices affects the perception of the work-home interaction: it results in an increase in employees' perception of the negative impacts of work life on non-work life.

Hypothesis $3 \mathbf{b} \mathbf{( H 3 b ) . ~ T h e ~ i n c r e a s e ~ i n ~ t h e ~ f r e q u e n c y ~ o f ~ u s i n g ~ t e c h n o l o g i e s ~ i n ~ t h e ~ c o n t e x t ~ o f ~}$ nomadic and informal work practices affects the perception of the work-home interaction: it results in an increase in employees' perception of the positive impacts of work life on non-work life.

Hypothesis 4a (H4a). High levels of frequent use of technology in the context of nomadic, informal and mediatised work practices result in an increase in addiction to work.

Hypothesis $4 \mathbf{b} \mathbf{( H 4 b ) . ~ H i g h ~ l e v e l s ~ o f ~ f r e q u e n t ~ u s e ~ o f ~ t e c h n o l o g y ~ i n ~ t h e ~ c o n t e x t ~ o f ~ n o m a d i c , ~ i n f o r m a l ~}$ and mediatised work practices result in an increase in addiction to the internet.

\section{Materials and Methods}

\subsection{Research Questionnaire}

The study was conducted in the Île-de-France region by using a self-completed questionnaire by French workers in the service sector that are engaged in nomadic, informal and ICT-mediatised work practices. The description of the questionnaire mentioned as inclusion criteria the use of technologies "outside the walls" of the organization, for professional purposes, as well as having nomadic, informal and ICT-mediatised work practices and working full time. The composition of the questionnaire is described in Tables 1 and 2. 
Table 1. Composition of the first part of the research questionnaire (nomadic, informal and mediatised work characteristics).

\begin{tabular}{ccl}
\hline $\begin{array}{c}\text { Characteristics of Nomadic, Informal and } \\
\text { Mediatised Work Practices }\end{array}$ & Number of Items & \multicolumn{1}{c}{ Item Details } \\
\hline Frequency of use of technologies & 3 & $\begin{array}{l}\text { 1. Smartphone/mobile phone } \\
\text { 2. Laptop computer } \\
\text { 3. Tablet }\end{array}$ \\
\hline Work places & $\begin{array}{l}\text { 1. Public transport (bus, train, plane, high-speed } \\
\text { train, etc.) } \\
\text { 2. Home } \\
\text { 3. Dedicated work spaces (co-working and } \\
\text { telecentres) } \\
\text { 4. Public spaces (cafes, restaurants, railway } \\
\text { stations and libraries) }\end{array}$ \\
\hline Time of day & 4 & $\begin{array}{l}\text { Early morning, morning, } \\
\text { afternoon, during breaks, late afternoon, evening } \\
\text { and night-time }\end{array}$ \\
\hline
\end{tabular}

Table 2. Composition of the multidimensional scales in the second part of the research questionnaire.

\begin{tabular}{|c|c|c|}
\hline Measuring Scales & Number of Items & Details of Dimensions/Items \\
\hline $\begin{array}{l}\text { Organisational Commitment } \\
\text { (Stinglhamber and Vandenberghe, 2002) }\end{array}$ & 18 & $\begin{array}{l}\text { 1. Affective commitment ( } 6 \text { items) } \\
\text { 2. Normative commitment ( } 6 \text { items) } \\
\text { 3. Perceived sacrifices ( } 3 \text { items) } \\
\text { 4. Perceived lack of employment alternatives ( } 3 \text { items) }\end{array}$ \\
\hline $\begin{array}{l}\text { Perceived recognition at work } \\
\qquad(\text { Fall, 2013) }\end{array}$ & 12 & $\begin{array}{l}\text { 1. Recognition from company ( } 4 \text { items) } \\
\text { 2. Recognition from superiors ( } 4 \text { items) } \\
\text { 3. Recognition from colleagues ( } 4 \text { items) }\end{array}$ \\
\hline $\begin{array}{c}\text { Work-Home Interaction } \\
\text { (Lourel, Gana and Wawrzyniak, 2005) }\end{array}$ & 13 & $\begin{array}{l}\text { 1. Negative effects of work life on private life ( } 8 \text { items) } \\
\text { 2. Positive effects of work life on private life }(5 \text { items })\end{array}$ \\
\hline $\begin{array}{l}\text { Compulsive Internet Use Scale } \\
\text { (Khazaal et al., 2012) }\end{array}$ & 14 & $\begin{array}{l}\text { 1. Loss of control ( } 4 \text { items) } \\
\text { 2. Concern about Internet use ( } 3 \text { items) } \\
\text { 3. Withdrawal symptoms ( } 1 \text { item) } \\
\text { 4. Mood changes or coping ( } 2 \text { items) } \\
\text { 5. Conflict ( } 4 \text { items) }\end{array}$ \\
\hline $\begin{array}{l}\text { Dutch Work Addiction Scale } \\
\text { (Sandrin and Gillet, 2016) }\end{array}$ & 10 & $\begin{array}{l}\text { 1. Excessive work ( } 5 \text { items) } \\
\text { 2. Compulsive work ( } 5 \text { items) }\end{array}$ \\
\hline
\end{tabular}

Participants were first asked to describe the characteristics of their nomadic, informal and ICT-mediatised work situations. They were asked to indicate the frequency of their uses of the various technologies and the locations of these practices "outside the walls" of the company, according to a four-level Likert scale (ranging from "Never" to "Always"). The participants were also asked to select the different times of day during which they carried out their nomadic, informal and mediatised work practices (morning, afternoon, night-time, etc.).

The workers were then asked to answer the questionnaire according to six measuring scales. All scales have already been validated in French and include Likert-type response scales.

The workers' perception of social approval on the part of their professional entourage was evaluated with an item, the wording of which ("Do you think that the following people approve or, on the contrary, do not approve of the fact that you carry out mediatised work activities 'outside the walls' of your company?") was inspired by the measure suggested by Pouchard et al. [56] on a scale ranging from 1 "Does not approve at all" to 5 "Approves completely".

Organisational commitment was assessed by using the validated 18-item scale (ranging from 1 "Not at all" to 5 "Very much") developed by Stinglhamber and Vanden- 
berghe [57]. Our study refers to the three-dimensional model of organisational commitment developed by Meyer and Allen [58], according to which commitment is a state of mind or psychological state referring to feelings and/or beliefs about an employee's relationship to their organization. Organizational commitment involves three components. Affective commitment corresponds to an identification and emotional attachment to the company and gathers 6 items (e.g., "My organization means a lot to me"). Normative commitment refers to an attitude of loyalty towards the company resulting from a feeling of obligation towards it and includes 6 items (e.g., "It would not be morally right to leave my current organisation now"). Finally, continuity commitment is based on the acknowledgement of the costs associated with breaking the relationship with the organization. It is divided between perceived sacrifices, which reflect the commitment on the basis of the sacrifices that leaving the company would involve (e.g., "I would not want to leave my current organisation because I would have a lot to lose," 3 items), and perceived lack of job alternatives, which refers to the awareness of an absence of job alternatives (e.g., "I am staying in my current organisation because I don't see where else I can go," 3 items).

Work recognition was measured using the work recognition scale developed by Fall in 2013 [59], comprising 12 items (ranging from 1 "Not at all" to 5 "Very much"). We used the conception of perceived work recognition based on the work of Brun and Dugas [60], who consider it as a constructive reaction, based on a judgment of the employee's contribution both in terms of work practices and personal dedication and commitment, which is delivered on a regular or occasional basis with formal or informal; individual or collective; public or private; and monetary or non-monetary manifestations. Perceived work recognition involves three dimensions: coming from the company (e.g., "My company gives me opportunities for advancement," 4 items), from hierarchical superiors (e.g., "My superiors listen to me when I need to talk to them about my work," 4 items) and co-workers (e.g., "My co-workers give me a spontaneous appreciation of the quality of my work," 4 items). This modelling has the advantage of taking into account the perceptions of those considered to be the "very sources of this recognition within the organization" [59] (p. 192).

Work-home interaction was assessed using the "SWING" scale (Survey Work-Home Interaction-Nijmegen) developed by Geurts ([61]; French version by Lourel, Gana and Wawrzyniak [62]). The interaction between work and non-work life refers to the relationship between one's professional (work activity) and private life (family activities, hobbies, etc.). According to Lourel and others, "work-life interaction mediates the relationship between work activity and subjective wellbeing" (p. 228). Based on Geurts' conception, such interaction is characterized by four dimensions subdivided into 22 items: the positive effects of work life on private life, which correspond to a better organisation of private life thanks to the professional activity carried out (e.g., "you can fulfill your obligations at home better because your work also requires it," 5 items); the negative effects of work life on private life, which refers to an invasion of private life by work life (e.g., "you find it difficult to fulfill your family obligations because you are always thinking about your work," 8 items); the positive effects of private life on work life, which consist in a more efficient management of work activity due to the way private life is organised (e.g., "you manage your time at work more efficiently because you have to do it at home too," 5 items); and the negative effects of private life on work life, which correspond to a spillover of domestic problems into work life (e.g., "you find it difficult to concentrate on your work because you are preoccupied with family problems," 4 items). According to the objectives of our study, we retained only the 13 items of the SWING scale relating to the perceived impacts of work life on private life, which includes impacts that are both negative and positive. These items are measured on a scale ranging from 0 "Never" to 3 "Always."

Internet addiction was measured by using the 14-item Compulsive Internet Use Scale developed by Meerkerk et al. [63]. We used the validated French version by Khazaal, Chatton and Horn et al. [64]. This scale is based on Meerkerk et al. [63] and is unidimensional. Internet addiction is defined as "an excessive and uncontrolled pattern of use impacting upon daily living" [64] (p. 398) and takes into account all aspects of the syndrome through 
five dimensions. Loss of control refers to an inability or unsuccessful efforts to reduce or control Internet use (e.g., "How often do you find it difficult to stop using the Internet while you are online?", 4 items). Concern about use made of the internet corresponds to worries about the possibilities of accessing the internet (e.g., "How often do you think about the Internet even when you are not online?", 3 items). Withdrawal symptoms refer to difficulty in putting the internet aside for other activities (e.g., "How often do you feel agitated, frustrated or irritated when you can't use the Internet?", 1 item). Mood changes (or coping) designate mood alterations, good or bad, associated with internet use ("How often do you go online when you feel down?", 2 items). Finally, the dimension of interpersonal conflicts involves the feeling of having to limit Internet use while experiencing difficulties in doing so (e.g., "How often do you think you should use the Internet less?", 4 items). Items are measured on a scale from 1 "Never" to 5 "Very Often".

Finally, work addiction was assessed using the 10-item Dutch Work Addiction Scale by Schaufeli, Shimazu and Taris ([65]; French version by Sandrin and Gillet [66]). It is defined as having a pathological relationship with work, "a compulsion or uncontrollable need to work constantly" [66] (p. 148). For Schaufeli, Taris and van Rhenen [67], work addiction should be considered in terms of two dimensions: excessive work (e.g., "I continue to work after my colleagues have left," 5 items), which designates the tendency to work excessively, and compulsive work (e.g., "I feel obliged to work intensely even if it is not pleasant," 5 items), which refers to the fact of being obsessed with work. Items are measured on a scale from 1 "Never" to 5 "Always".

\subsection{Identification of the Population and Establishing Contact with Participants}

We used the random sampling method to recruit participants, as nomadic, informal and mediatised work covers a wide variety of professional situations. We also used the snowball sampling method [68], which enabled us to use one participant to make contact with other potential participants. We must specify that our sample was collected in the pre-pandemic context of COVID-19.

The workers were contacted in four ways: through their companies (we favoured organisations known to be linked to nomadic practices requiring the use of technologies, such as large private companies or universities), within the spaces they might frequent as nomadic workers (co-working places), via professional networks (of managers and consultants as well as remote workers) and, finally, on the basis of explicit announcements posted on social networks.

\subsection{Socio-Demographic Characteristics of the Sample and Typology of Nomadic, Informal and Mediatized Work Practices}

The sample was made up of 380 French workers engaged in nomadic, informal and mediatised work practices. Most of these workers were employed in the private sector (75.8\%). The employees were mainly company executives (35.5\%). Most of them were not involved in supervising others employees $(60.3 \%)$ and came from small and medium-sized companies $(29.5 \%)$ as well as from very large companies $(27.4 \%)$. The employees have been engaged in nomadic, informal and mediated work practices for an average period of 8 years. There was an equal proportion of men $(50.8 \%)$ and women $(49.2 \%)$. The average age of the participants was 38.3 years. Most of the participants were living as a couple $(64.7 \%)$, and $38.9 \%$ were living with their children.

The characteristics of nomadic, informal and mediatised work practices experienced by the participants were the subject of in-depth interest in order to understand and clarify them. The participants favoured the use of smartphones/mobile phones and laptops for these work practices. The places of work "outside the walls" of the company where work was carried out were, above all, the home and, to a lesser extent, public transport. These characteristics are detailed in Table 3. 
Table 3. Details of the frequency of use of technologies (in percentages).

\begin{tabular}{ccccc}
\hline & Never & Rarely & Often & Always \\
\hline Technologies & & & & \\
\hline Smartphone/mobile phone & 7.1 & 12.9 & 29.2 & 50.8 \\
\hline Laptop computer & 5 & 14.2 & 28.4 & 52.4 \\
\hline Tablet & 65 & 21.6 & 9.5 & 3.9 \\
\hline Work Places & & & & \\
\hline Public transport & 21.8 & 34.7 & 31.8 & 11.6 \\
\hline Home & 3.4 & 13.9 & 43.9 & 38.7 \\
\hline $\begin{array}{c}\text { Places dedicated to work } \\
\text { (co-working places, etc.) }\end{array}$ & 58.2 & 17.9 & 15.5 & 6.8 \\
\hline $\begin{array}{c}\text { Non-dedicated places } \\
\text { (restaurants, etc.) }\end{array}$ & 38.4 & 35.8 & 18.9 & \\
\hline
\end{tabular}

The responses indicate that these nomadic, informal and mediatised work practices extended over fairly diverse periods of the day and not only occurred most often before or at the start of the working day (45.3\% in the early morning; $46.6 \%$ in the morning) and at the end of the working day ( $53.4 \%$ in the late afternoon; $46.1 \%$ in the evening) but also sometimes at night after standard bedtime hours (15.3\%).

Nomadic, informal and mediatised work as practised by the participants, thus, appears to include spillover work, extended to periods of time traditionally devoted to life "outside of work" and to journeys between home and the official workplace (practices while using public transport).

\subsection{Analysis Procedure}

In this study, we performed first a structural equation analysis (path analysis) using SmartPLS software to test our research model. Next, we carried out multiple regressions analysis by using Jamovi software.

\section{Results}

\subsection{Descriptive Statistics for Variables Making up the Research Model}

In order to test the reliability of the measuring scales, we calculated Cronbach's alphas $(\alpha)$ for each of the dimensions and subdimensions considered (see Table 4). Based on the findings of Mohamad et al. (2015) [69], we considered $\alpha$ to be acceptable at 0.60 and quite correct at 0.70 .

After cleaning up two items in the organisational commitment scale, every dimension has an alpha of above 0.75 , which is quite satisfactory. Moreover, the alphas calculated for the different subdimensions range from 0.91 for the highest to 0.69 for the lowest. We can, therefore, conclude that the internal fidelity of all the scales is correct.

Table 4. Descriptive statistics for variables included in the research model.

\begin{tabular}{|c|c|c|c|c|c|}
\hline & M-SD & Median & Min-Max & $\begin{array}{c}\text { Min-Max } \\
\text { (Theoretical) }\end{array}$ & $\alpha$ \\
\hline Approval of the professional entourage & $3.77-1.03$ & 4 & $1-5$ & $1-5$ & - \\
\hline Organisational Commitment & $2.83-0.67$ & 2.83 & $1.2-5$ & $1-5$ & 0.88 \\
\hline Affective commitment & $2.35-0.54$ & 2.33 & $1-4.1$ & $1-5$ & 0.77 \\
\hline Normative commitment & $2.70-1.14$ & 2.58 & $1-5$ & $1-5$ & 0.91 \\
\hline Perceived sacrifices & $2.91-1.11$ & 3 & $1-5$ & $1-5$ & 0.80 \\
\hline Perceived lack of employment alternatives & $2.35-1.03$ & 2.33 & $1-5$ & $1-5$ & 0.78 \\
\hline
\end{tabular}


Table 4. Cont.

\begin{tabular}{|c|c|c|c|c|c|}
\hline & M-SD & Median & Min-Max & $\begin{array}{c}\text { Min-Max } \\
\text { (Theoretical) }\end{array}$ & $\alpha$ \\
\hline Perceived recognition at work & $3.62-0.73$ & 3.58 & $1.2-5$ & $1-5$ & 0.88 \\
\hline Company & $3.30-0.96$ & 3.25 & $1-5$ & $1-5$ & 0.80 \\
\hline Superiors & $3.77-0.92$ & 4 & $1-5$ & $1-5$ & 0.86 \\
\hline Colleagues & $3.80-0.82$ & 3.75 & $1.5-5$ & $1-5$ & 0.84 \\
\hline Work-Life Interaction & $1.20-0.49$ & 1.23 & $0-2.7$ & $0-3$ & 0.78 \\
\hline Negative effects of work on "non work" life & $1.10-0.65$ & 1 & $0-3$ & $0-3$ & 0.87 \\
\hline Positive effects of work on "non work" life & $1.36-0.69$ & 1.4 & $0-3$ & $0-3$ & 0.75 \\
\hline Internet Addiction & $2.32-0.75$ & 2.28 & $1-4.6$ & $1-5$ & 0.89 \\
\hline Loss of control & $2.55-0.91$ & 2.5 & $1-5$ & $1-5$ & 0.74 \\
\hline Concern about Internet use & $2.18-0.85$ & 2 & $1-4.6$ & $1-5$ & 0.69 \\
\hline Withdrawal symptoms & $2.30-1.15$ & 2 & $1-5$ & $1-5$ & - \\
\hline Mood modification or coping & $2.35-1.09$ & 2 & $1-15$ & $1-5$ & 0.85 \\
\hline Conflict & $2.20-0.84$ & 2 & $1-5$ & $1-5$ & 0.71 \\
\hline Work Addiction & $2.56-0.53$ & 2.60 & $1.2-4$ & $1-5$ & 0.78 \\
\hline Excessive work & $2.76-0.59$ & 2.80 & $1-4$ & $1-5$ & 0.69 \\
\hline Compulsive work & $2.36-0.63$ & 2.40 & $1-4$ & $1-5$ & 0.69 \\
\hline
\end{tabular}

\subsection{Testing of the General Research Model}

As mentioned above, we first tested the relevance of our initial model by means of path analysis using SmartPLS software according to the least squares procedure, which allowed us to test models with smaller samples, and bootstrapping (1000 samples, 95\% confidence interval).

The results of our structural equation analysis enable us not only to check how closely the data obtained in our study fit our initial research model but also to highlight the indirect effects of our variables and the effects of each factor included in the model. The following indexes and criteria were used: SRMR $(<0.08)$, NFI (the closer the indicator is to one, the better the fit of the model), chi-squared $\left(\mathrm{Chi}^{2}\right)$ and RMS-Theta (the closer the indicator is to zero, the better the fit of the model).

Since our initial model was not satisfactory, we conducted additional analyses with other models in order to obtain one that would fit our data more adequately (see Table 5).

Table 5. Research model adequacy indexes.

\begin{tabular}{ccccc}
\hline & SRMR & NFI & Chi $^{\mathbf{2}}$ & RMS_Theta \\
\hline IM & 0.101 & 0.516 & 1126.983 & 0.183 \\
\hline FM & 0.064 & 0.706 & 597.020 & 0.163 \\
\hline
\end{tabular}

Notes: $\mathrm{MI}$ = initial model tested; FM = final model.

The final model is presented in Figure 2. The results model provides initial indications of the relevance of research hypotheses $\mathrm{H} 1$ to $\mathrm{H} 4$.

Firstly, we find that perceived social approval on the part of the professional entourage tends to favour more frequent use of the laptop in the context of nomadic and informal work practices. On the other hand, our results do not indicate any significant links between perceived approval and the frequency of use of the other two technologies (smartphone and tablet). Similarly, there are only indirect links between social approval and all the processes examined, links that are totally mediatised by the frequency of laptop use. 


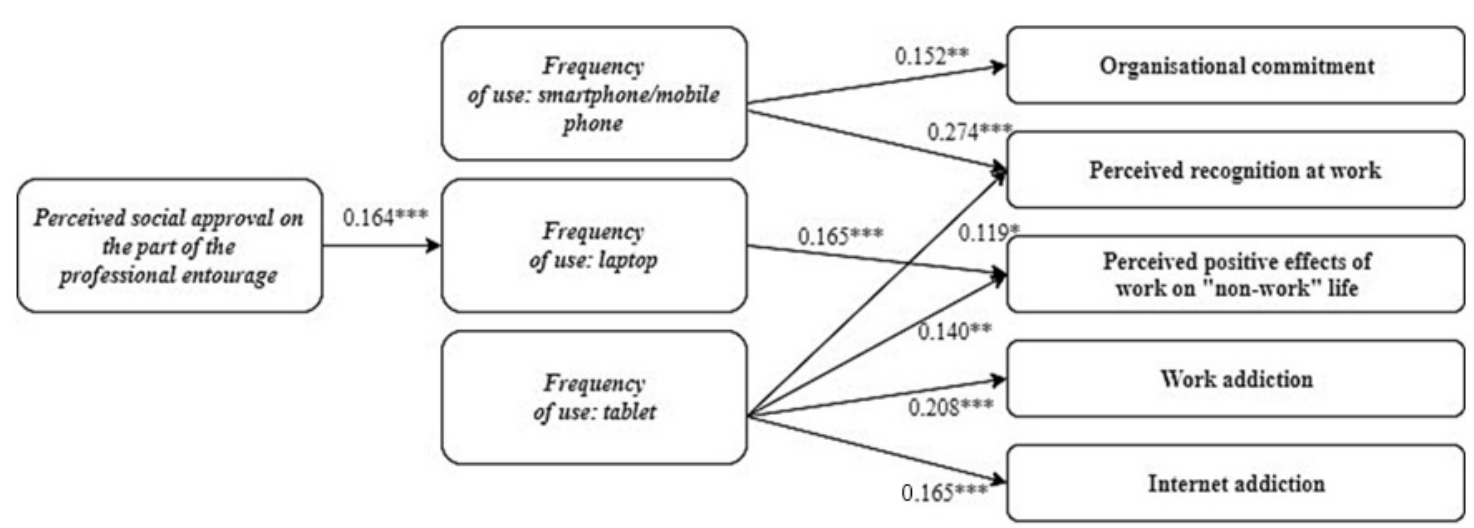

Figure 2. Structural equation model. Notes: Standardised beta coefficients presented with the following: ${ }^{*} p<0.05$, ${ }^{* *} p<0.01,{ }^{* * *} p<0.001$. Non-significant causal leads have been removed.

This finding qualifies our first hypothesis (H1). Indeed, perceived social approval is only significantly and positively correlated with the frequency of use of one of the mobile technologies studied (the laptop), even though other mobile technologies (the smartphone) also appear to be frequently used in nomadic, informal and mediatised work practices of the participants in our study (see Table 3).

The results of the structural equation modelling also result in the qualification of hypotheses $\mathrm{H} 2, \mathrm{H} 3$ and $\mathrm{H} 4$ because they indicate that the frequencies of use of each of the three mobile technologies are specifically associated with the dimensions studied.

Thus, with regard to hypothesis H2a, it appears that only the frequencies of use of the smartphone and the tablet are positively related to the level of organisational commitment. As for hypothesis $\mathrm{H} 2 \mathrm{~b}$, it is only the frequency of use of the smartphone that is positively associated with the degree of perceived recognition at work.

Hypothesis H3a is refuted: The increase in the frequency of use of mobile technologies (smartphone, laptop and tablet) in the context of informal nomadic work practices is not significantly associated with an increase in the perceived negative effects of work life on life "outside work." Hypothesis H3b is only confirmed for the use of the tablet; the frequency of use of this technology during informal nomadic work is positively correlated with the perception of positive effects between work and non-work life.

Hypothesis H4a posited that very frequent use of mobile technology in informal nomadic work practices would cause an increase in work addiction. In this sense, the results indicate that the more frequent the use of laptop and tablet tends to be, the more workers are likely to perceive work addiction. On the other hand, the link between frequency of smartphone use and degree of work addiction is not significant. Hypothesis $\mathrm{H} 4 \mathrm{~b}$ is confirmed only for tablet use: the frequency of use of this mobile technology is positively associated with the phenomenon of internet addiction.

In order to clarify these initial results obtained by structural equation analysis, additional analyses were conducted by using multiple regression. The aim was to further examine firstly the $\mathrm{H} 2$ hypothesis relating to how workers perceived their relationship to work by considering the various subdimensions of organisational commitment and perceived recognition at work and, secondly, the $\mathrm{H} 4$ hypothesis relating to health by taking into account each of the components of work and internet addiction.

\subsection{Additional Results Using Multiples Regression Analyses}

4.3.1. Influence of Frequency of Use of Technologies in the Context of Nomadic and Informal Work Practices on Organisational Commitment (H2a) and Perceived Recognition at Work $(\mathrm{H} 2 \mathrm{~b})$

The results presented in Table 6 specify the effects of the frequency of the different uses of mobile technologies on each of the components of commitment (affective commitment, normative commitment, perceived sacrifices and perceived lack of employment 
alternatives). The three types of mobile technologies used have differing effects on the components of commitment, focused specifically on certain subdimensions of commitment.

Table 6. Multiple linear regressions and correlations: effects of frequency of use of the technologies (smartphone/mobile phone, laptop and tablet) on organisational commitment.

\begin{tabular}{|c|c|c|c|c|c|}
\hline & $\begin{array}{c}\text { Affective } \\
\text { Commitment }\end{array}$ & $\begin{array}{l}\text { Normative } \\
\text { Commitment }\end{array}$ & $\begin{array}{l}\text { Perceived } \\
\text { Sacrifices }\end{array}$ & $\begin{array}{c}\text { Lack of } \\
\text { Alternatives }\end{array}$ & Total Score \\
\hline Smartphone & $\begin{array}{c}0.204^{* * *} \\
B=0.190^{* * *}\end{array}$ & $\begin{array}{c}0.107 * \\
B=0.093\end{array}$ & $\begin{array}{c}0.057 \\
B=0.040\end{array}$ & $\begin{array}{c}-0.100 \\
B=-0.115 *\end{array}$ & $\begin{array}{c}0.091 \\
B=0.070\end{array}$ \\
\hline Laptop & $\begin{array}{c}0.096 \\
B=0.074\end{array}$ & $\begin{array}{c}0.028 \\
B=0.010\end{array}$ & $\begin{array}{c}0.126^{*} \\
B=0.117 \text { * }\end{array}$ & $\begin{array}{c}0.070 \\
B=0.073\end{array}$ & $\begin{array}{c}0.085 \\
B=0.068\end{array}$ \\
\hline Tablet & $\begin{array}{c}0.093 \\
B=0.070\end{array}$ & $\begin{array}{c}0.155^{* *} \\
B=0.145^{* *}\end{array}$ & $\begin{array}{c}0.085 \\
B=0.072\end{array}$ & $\begin{array}{c}0.092 \\
B=0.097\end{array}$ & $\begin{array}{c}0.163^{* *} \\
B=0.151^{* *}\end{array}$ \\
\hline & $\begin{array}{c}\text { Adjusted } \mathrm{R}^{2}= \\
0.044^{* * *} \\
\mathrm{~F}(3)=6.94^{* * *}\end{array}$ & $\begin{array}{c}\text { Adjusted } \mathrm{R}^{2}= \\
0.025^{* *} \\
\mathrm{~F}(3)=4.27^{* *}\end{array}$ & $\begin{array}{c}\text { Adjusted } \mathrm{R}^{2}= \\
0.015^{*} \\
\mathrm{~F}(3)=2.99 *\end{array}$ & $\begin{array}{c}\text { Adjusted } R^{2}= \\
0.018^{*} \\
F(3)=3.32 *\end{array}$ & $\begin{array}{c}\text { Adjusted } \mathrm{R}^{2}= \\
0.029^{* *} \\
\mathrm{~F}(3)=4.81^{* *}\end{array}$ \\
\hline
\end{tabular}

Notes: Standardised regression coefficients (B) presented with the following: ${ }^{*} p<0.05,{ }^{* *} p<0.01,{ }^{* * *} p<0.001$.

Thus, the frequency of smartphone use is positively associated with the level of affective commitment to the organisation $(p<0.001)$ and, to a lesser extent, with levels of normative commitment $(p<0.05)$ and perceived lack of employment alternatives $(p<0.05)$. Frequency of laptop use is only related to the perceived sacrifice component $(p<0.05)$, and frequency of tablet use is related only to the normative commitment component $(p<0.01)$.

The results presented in Table 7 show the effects of the frequency of using different mobile technologies on each of the components of perceived recognition at work (perceived recognition on the part of the company, superiors and colleagues). The frequency of smartphone use is positively associated with each of the dimensions of perceived work recognition $(p<0.001)$. The effects of the frequency of use of the other two technologies (laptop and tablet) on the components of recognition are less strongly established. However, it is worth noting the positive correlations between the frequency of laptop use on the levels of perceived recognition on the part of superiors $(p<0.05)$ and colleagues $(p<0.05)$ as well as the positive effect of the frequency of tablet use on perceived recognition on the part of the company $(p<0.05)$.

Table 7. Multiple linear regressions and correlations: effects of frequency of use of the technologies (smartphone/mobile phone, laptop and tablet) on perceived job recognition.

\begin{tabular}{|c|c|c|c|c|}
\hline & Recognition-Company & Recognition-Superiors & Recognition-Colleagues & Total Score \\
\hline Smartphone & $\begin{array}{c}0.214^{* * *} \\
B=0.202^{* * *}\end{array}$ & $\begin{array}{c}0.227 * * * \\
B=0.218^{* * *}\end{array}$ & $\begin{array}{c}0.249 * * * \\
B=0.240^{* * *}\end{array}$ & $\begin{array}{c}0.283^{* * *} \\
B=0.271^{* * *}\end{array}$ \\
\hline Laptop & $\begin{array}{c}0.041 \\
B=0.016\end{array}$ & $\begin{array}{c}0.119 * \\
B=0.100 *\end{array}$ & $\begin{array}{c}0.114^{*} \\
B=0.093\end{array}$ & $\begin{array}{c}0.111 * \\
B=0.084\end{array}$ \\
\hline Tablet & $\begin{array}{c}0.132 * \\
B=0.112 *\end{array}$ & $\begin{array}{c}0.024 \\
B=-0.003\end{array}$ & $\begin{array}{c}0.035 \\
B=0.006\end{array}$ & $\begin{array}{c}0.081 \\
B=0.050\end{array}$ \\
\hline & $\begin{array}{c}\text { Adjusted } R^{2}=0.051 * * * \\
F(3)=7.83^{* * *}\end{array}$ & $\begin{array}{c}\text { Adjusted } \mathrm{R}^{2}=0.053^{* * *} \\
\mathrm{~F}(3)=8.19^{* * *}\end{array}$ & $\begin{array}{c}\text { Adjusted } R^{2}=0.063 * * * \\
F(3)=9.58^{* * *}\end{array}$ & $\begin{array}{c}\text { Adjusted } R^{2}=0.082^{* * *} \\
F(3)=12.4^{* * *}\end{array}$ \\
\hline
\end{tabular}

Notes: Standardised regression coefficients (B) presented with the following: ${ }^{*} p<0.05,{ }^{* * *} p<0.001$.

4.3.2. Influence of Frequency of Use of Technologies on Work Addiction (H4a) and Internet Addiction (H4b) in the Context of Nomadic and Informal Work Practices

The results presented in Table 8 specify the effects of the frequency of the various uses of mobile technologies on each of the components of work addiction (excessive work and compulsive work). It appears that the frequency of tablet use affects the level of excessive work $(p<0.01)$ and the level of compulsive work $(p<0.001)$. The frequency of laptop use 
also affects the levels of these two components ( $p<0.01$ and $p<0.05$, respectively). The results obtained confirm that the frequency of smartphone use is not associated with work addiction and does not affect either the excessive work or compulsive work components.

Table 8. Multiple linear regressions and correlations: effects of frequency of use of technologies (smartphone/mobile phone, laptop and tablet) on work addiction.

\begin{tabular}{cccc}
\hline & Excessive Work & Compulsive Work & Total Score \\
\hline \multirow{2}{*}{ Smartphone } & 0.082 & -0.008 & 0.040 \\
& $B=0.055$ & $B=-0.036$ & $B=0.009$ \\
\hline \multirow{2}{*}{ Laptop } & $0.165^{* *}$ & $0.109^{*}$ & $0.156^{* *}$ \\
& $B=0.150^{* *}$ & $B=0.097$ & $B=0.140^{* *}$ \\
\hline \multirow{2}{*}{ Tablet } & $0.159^{* *}$ & $0.221^{* * *}$ & $0.218^{* * *}$ \\
& $B=0.143^{* *}$ & $B=0.217^{* * *}$ & $B=0.207^{* * *}$ \\
\hline Adjusted $R^{2}=0.044^{* * *}$ & Adjusted $\mathrm{R}^{2}=0.051^{* * *}$ & Adjusted $\mathrm{R}^{2}=0.060^{* * *}$ \\
& $\mathrm{~F}(3)=0164$ & $\mathrm{~F}(3)=7.87^{* * *}$ & $\mathrm{~F}(3)=9.07^{* * *}$ \\
\hline Notes: Standardised regression coefficients (B) presented with the following: ${ }^{*} p<0.05,{ }^{* *} p<0.01^{* * *} p<0.001$.
\end{tabular}

The results presented in Table 9 show the effects of the frequency of the different uses of mobile technologies on each of the components of internet addiction. The results point to significant effects of the frequency of tablet use on several of the components of internet addiction: preoccupation $(p<0.001)$ and conflict $(p<0.001)$ as well as, to a lesser extent, loss of control $(p<0.01)$ and withdrawal $(p<0.05)$. The frequency of smartphone use was associated only with the loss of control component. Finally, the results obtained confirm that the frequency of laptop use is not associated with internet addiction and does not affect any of its components.

Table 9. Multiple linear regressions and correlations: effects of frequency of use of the technologies (smartphone/mobile phone, laptop and tablet) on Internet addiction.

\begin{tabular}{|c|c|c|c|c|c|c|}
\hline & Loss of Control & Concern & Withdrawal & Mood Change & Conflict & Total Score \\
\hline \multirow{2}{*}{ Smartphone } & $0.152 *$ & 0.078 & 0.003 & 0.037 & 0.051 & 0.097 \\
\hline & $B=0.134^{* *}$ & $B=0.063$ & $B=-0.011$ & $B=0.031$ & $B=0.029$ & $B=0.077$ \\
\hline \multirow{2}{*}{ Laptop } & 0.096 & 0.011 & 0.055 & -0.003 & 0.053 & 0.059 \\
\hline & $B=0.076$ & $B=-0.005$ & $B=0.048$ & $B=-0.064$ & $B=0.036$ & $B=0.040$ \\
\hline \multirow{4}{*}{ Tablet } & $0.134 * *$ & $0.174^{* * *}$ & $0.114 *$ & 0.079 & $0.204^{* * *}$ & $0.184^{* * *}$ \\
\hline & $B=0.116^{*}$ & $B=0.168^{* *}$ & $B=0.111^{*}$ & $B=-0.064$ & $B=0.198^{* * *}$ & $B=0.174^{* * *}$ \\
\hline & $\underset{* * *}{\text { Adjusted } \mathrm{R}^{2}}=0.035$ & $\begin{array}{c}\text { Adjusted } R^{2}= \\
0.026^{* *}\end{array}$ & \multirow{2}{*}{$\begin{array}{c}\text { Adjusted } R^{2}=0.007 \\
F(3)=1.94\end{array}$} & $\begin{array}{c}\text { Adjusted } R^{2}= \\
-0.000\end{array}$ & $\underset{* * *}{\text { Adjusted } \mathrm{R}^{2}}=0.036$ & Adjusted $\mathrm{R}^{2}=0.034$ \\
\hline & $\mathrm{F}(3)=5.70^{* * *}$ & $\mathrm{~F}(3)=4.44^{* *}$ & & $F(3)=0.908$ & $\mathrm{~F}(3)=5.75^{* * *}$ & $\mathrm{~F}(3)=5.49^{* *}$ \\
\hline
\end{tabular}

Notes: Standardised regression coefficients (B) presented with the following: ${ }^{*} p<0.05,{ }^{* *} p<0.01,{ }^{* * *} p<0.001$.

\section{Discussion}

It should be recalled that our study sought to understand the relationship between perceived social approval on the part of the workers' professional entourage, the uses of the technologies mobilised in connection with these practices and the impacts of these uses on employees' relationships with the organisation, their work-life balance and their health.

As we posited, our results converge with those that have highlighted the impacts of the perception on the part of the professional entourage of remote and mediatised work on the implementation of these practices and their different characteristics [20,26,27]. However, in the context of the nomadic and informal work practices we analysed, perceived social approval only affects the frequency of daily use of one of the technologies considered: the laptop. Contrary to what we might have expected, the perception of approval on the part of the employee's professional entourage does not encourage more frequent use of the other two mobile technologies considered in our study (smartphone/mobile phone and tablet). 
Our study happens to be in line with other studies that have shown how the use of technologies in the context of remote working practices results in an increase in organisational commitment [23], potentially fostered by the increase in work autonomy offered by these technologies and, more globally, by remote work $[25,29]$. As expected, our results identified the targeted effects of the frequency of each of the three uses of mobile technologies on the components of organisational commitment.

The findings of our analyses tend to support other studies that have shown that using ICTs in the workplace makes communication and the exchange of information among employees quicker and more fluid $[4,33]$. In particular, we found that, in the context of nomadic and informal work practices, the frequency of smartphone use has a positive effect on the level of perceived recognition at work on the part of the company and employees' superiors and colleagues. Such findings lead us to question research that has found that recognition at work decreases in remote and mediatised work situations due to isolation, physical distance and the lack of spontaneous interactions with colleagues caused by these professional practices $[9,35]$.

Regarding the work-life balance, the results of our study support the conclusions of previous studies that have highlighted the positive effects of the use of technologies associated with telework practices on this same balance. Several studies have indicated that the use of ICTs in the context of teleworking enables employees to organise their work activities in such a way as to limit the constraints on their private life and to balance their life spheres more easily [70-72]. The use of technology in remote working situations has been identified as a factor in better management of work and "non-work" lives, resulting in rebalancing work, family and personal social time $[73,74]$. The tablet, along with the smartphone, has been identified as a technology particularly likely to change the spatial and temporal boundaries of work [75]. It appears that more frequent use of the tablet reinforces the perception of the positive impact of work life on "non-work" life, including flexibility and better management of family activities [37-39]. Contrary to our expectations, in the context of the nomadic and informal work practices we studied, the tablet is the only one of the three mobile technologies taken into account for which frequency of use favours the perception of positive effects of work life on "non-work" life.

The results of our study refined our understanding of the effects of the use of ICTs on addictions (to work and to the internet) in the context of nomadic, informal and mediatised work practices. Many researchers have indeed highlighted the deleterious impacts of remote and mediatised work in terms of work intensification and addiction $[10,50,51]$. The use of ICTs at work makes demands in terms of workers' availability and enhanced performance, which increases the risks of work addiction [52]. Furthermore, Vonthron and Vayre [3] advanced that the intensity of internet use in the professional context tends to reinforce the risks of internet addiction. ICT-facilitated access to the internet has been identified as resulting in more frequent use, with a consequently higher risk of addiction [76,77], but without detailed mention of the specific impacts relating to each technology used (smartphone, computer or tablet). In the context of informal and mediatised nomadic work, our study examined the specific effects of each of the mobile technologies used on addiction phenomena and confirmed our assumptions of the effects they would have. Our results indicate that the frequency of laptop and tablet use is associated with work addiction and that only the frequency of tablet use causes an increase in internet addiction.

However, the results obtained should be considered in the light of the main limitations of the study we carried out. Firstly, the data analysed were collected according to a cross-sectional procedure, which did not permit us to examine the effects of informal and mediatised nomadic work practices that may change over time. The size of our sample was also small and restricted, making it imperative to conduct further studies in this area in France in order to check whether similar results can be found in larger and more representative samples of the sectors and occupations that are likely to engage in this type of work practice. The perception of social approval on the part of the professional entourage may have impacts that cannot be captured here, modifying the frequency of 
use in the long term of the various mobile technologies deployed in the context of these practices. Moreover, the data processed are only self-reported by the participants, whereas data, particularly relating to their levels of work and internet addiction, could have been collected from professionals monitoring their health at work. Moreover, since our study was conducted in France, it did not, therefore, identify elements related to ICT accessibility, maturity, culture and uses in other countries. Future studies comparing France and other countries, both European and non-European, could therefore provide additional data to our findings. Similarly, participants were not asked to indicate whether the technologies used for their work activity were owned by them or provided by the company. If we can assume that the participants are to some extent provided with equipment by their employer, mainly for executives and managers, it would be interesting to investigate whether the fact of having mobile technologies provided by employers constitutes an implicit invitation to work with these technologies outside the walls of the company or not [3]. Future studies addressing these elements would, thus, be beneficial to a deeper understanding of the effects of the uses of technologies as part of nomadic, informal and mediatised work practices. They could also include other additional aspects, such as exploring the specificity of the work performed, the effects of employees' age, lifestyle and family life phase.

Finally, the participants were interviewed in the months preceding the global COVID19 pandemic. The obligations of social distancing imposed at that time in the French working world resulted in a strong development of workers' experience in working practices "outside the walls" of companies during the year 2020. The increased experience in this area in order to meet the need for continuity of professional activities during this period is undoubtedly not without influence on the current processes of workers' adjustment to nomadic, informal and mediatised work practices. Consequently, our study would benefit from being replicated in order to consolidate the results and to see whether the mechanisms are similar in a post-pandemic context.

Although subject to these limitations, our study was able to test an original research model. The results provided us with a better understanding of how use of the different mobile technologies forms part of nomadic, informal and mediatised work practices. We have been able to identify the weight of perceived social approval in their implementation and to precisely identify their effects on the dimensions and components of the relationship to work, the perceived work-home interaction and health.

\section{Conclusions}

From a scientific perspective, our study adds to existing knowledge in the field of work and organisational psychology. By focusing specifically on nomadic, informal and mediatised work practices, which are very little addressed in the literature, our results provide details on the use made of mobile technologies (smartphone/mobile phone, laptop and tablet) in today's work organisations, which are characterised by increasingly frequent multispatiality and increasingly vague time frames [2,4].

The results we obtained are interesting and original in that they offer a sharpened understanding of the effects of the use of technologies in the context of nomadic and informal work practices. The study sheds further light on the conclusions of previous work that has addressed the consequences for workers of their use of ICTs "outside the walls" of their company. It highlights the specific impacts of the frequency of such use on the various components of organisational commitment, perceived recognition at work and on work and internet addiction.

In view of the results obtained and also the limitations of the study, we feel that it is important to pursue empirical studies in this field, particularly with larger and transnational samples in order to support analyses in varied socio-cultural contexts of work "outside the walls" of companies. It would also be relevant to employ mixed data collection methods, both quantitative and qualitative, in order to refine our understanding of the uses of ICTs in the context of nomadic, informal and mediatised work practices and their effects on the various targeted processes. Interviews with workers and their professional entourage 
could shed more light on how colleagues, superiors and subordinates perceive their use of technologies in the workplace, as well as the impact of these perceptions on the uses. Other indicators of health or quality of life, including not only burnout but also other characteristics (preferred locations or times) of nomadic, informal and mediatised work practices, could be taken into account in the analyses in order to gain a better understanding of the different situations covered by these work practices and the manner they affect various aspects of workers' lives.

The processes addressed by our study (organisational commitment, perceived recognition at work and work-life balance) have been recognised as factors of individual and organisational performance [78-81]. The fact that the remote work practices studied are not contractualised and, therefore, are not regulated and not driven by organisations questions all the more their potential deleterious effects on employees and more specifically in connection with the use of technologies, as these have become indispensable tools for the accomplishment of professional tasks due to the increasing digitalisation of companies [81]. As we have observed, little research has as yet been conducted on questioning the effects of technologies in the context of remote and informal work practices, and the literature could, therefore, benefit from further study.

Today, the issues of voluntary limitation of the use of ICTs in the professional context and, more specifically, the issue of the "right to disconnect" [82] reinforce the value of developing more studies in this field. Despite the implementation of charters and prevention schemes in companies aimed at informing individuals of the risks of the intensive use of technologies, ICTs remain strongly linked to an improvement in the performance of organisations and an increased development of the product and service offer, thus promoting an increase in the number of customers and profits [83,84]. The use of mobile technologies is associated with a desire for companies to be efficient quickly in order to respond to customer demands and available at all times, while setting ever higher production targets: these elements tend to increase the potential for addictions developing in the professional setting and the extension of work outside the usual spaces and temporalities $[1,85,86]$.

The knowledge resulting from our study is, thus, intended to feed and reinforce the deployment of support and regulation systems for both the use of ICTs and nomadic, informal and mediatised work practices in order to contribute to the prevention of the associated occupational and psychosocial risks.

Author Contributions: Conceptualization, M.P., A.-M.V. and É.V.; methodology, M.P., A.-M.V. and É.V.; validation, A.-M.V. and É.V.; formal analysis, M.P.; investigation, M.P.; resources, M.P.; data curation, M.P.; writing-original draft preparation, M.P., A.-M.V. and É.V.; writing-review and editing, M.P., A.-M.V. and É.V.; visualization, M.P., A.-M.V. and É.V.; supervision, A.-M.V. and É.V.; project administration, M.P., A.-M.V. and É.V. All authors have read and agreed to the published version of the manuscript.

Funding: This research received no external funding.

Institutional Review Board Statement: Ethical review and approval were waived for this study since the research involves anonymized records.

Informed Consent Statement: Informed consent was obtained from all subjects involved in the study.

Data Availability Statement: The study did not report any data.

Conflicts of Interest: The authors declare no conflict of interest.

\section{References}

1. Thomas, K. Workplace Technology and the Creation of Boundaries: The Role of VHRD in a 24/7 Work Environment. Adv. Dev. Hum. Resour. 2014, 16, 281-295. [CrossRef]

2. Trenerry, B.; Chng, S.; Wang, Y.; Suhaila, Z.; Lim, S.; Lu, H.; Oh, P. Preparing Workplaces for Digital Transformation: An Integrative Review and Framework of Multi-Level Factors. Front. Psychol. 2021, 12, 620766. [CrossRef] 
3. Vayre, E.; Vonthron, A.-M. Identifying Work-Related Internet's Uses—at Work and Outside Usual Workplaces and Hours-and Their Relationships with Work-Home Interface, Work Engagement, and Problematic Internet Behavior. Front. Psychol. 2019, 10, 2118. [CrossRef]

4. De Wet, W.; Koekemoer, E.; Nel, J. Exploring the impact of information and communication technology on employees' work and personal lives. SA J. Ind. Psychol. 2016, 42, 1-11. [CrossRef]

5. Tissot Editions. Available online: https://www.editions-tissot.fr/actualite/droit-du-travail/73-des-cadres-declarent-travaillerhors-de-leur-bureau-et-etre-liberes (accessed on 10 October 2021).

6. Bailey, D.; Kurland, N. A review of telework research: Findings, new directions, and lessons for the study of modern work. J. Organ. Behav. 2002, 23, 383-400. [CrossRef]

7. Chen, L.; Nath, R. Nomadic Culture: Cultural Support for Working Anytime, Anywhere. Inf. Syst. Manag. 2005, 22, 56-64. [CrossRef]

8. Martin, B.; MacDonnell, R. Is telework effective for organizations? A meta-analysis of empirical research on perceptions of telework and organizational outcomes. Manag. Res. Rev. 2012, 35, 602-616. [CrossRef]

9. Aczel, B.; Kovacs, M.; van der Lippe, T.; Szaszi, B. Researchers working from home: Benefits and challenges. PLoS ONE 2021, 16, e0249127. [CrossRef] [PubMed]

10. Turel, O.; Serenko, A.; Bontis, N. Family and work-related consequences of addiction to organizational pervasive technologies. Inf. Manag. 2011, 48, 88-95. [CrossRef]

11. Hannif, Z.; Cox, A.; Almeida, S. The Impact of ICT, workplace relationships and management styles on the quality of work life: Insights from the call centre front line. Labour. Ind. 2014, 24, 69-83. [CrossRef]

12. Ojala, S. Supplemental Work at Home among Finnish Wage Earners: Involuntary Overtime or Taking the Advantage of Flexibility? Nord. J. Work. Life Stud. 2011, 1, 77-97. [CrossRef]

13. Lawson, K.; Davis, K.; Crouter, A.; O’Neill, J. Understanding work-family spillover in hotel managers. Int. J. of Hosp. Manag. 2013, 33, 273-281. [CrossRef]

14. Demerouti, E.; Derks, D.; Ten Brummelhuis, L.; Bakker, A. New ways of working: Impact on working conditions, work-family balance, and well-being. In The Impact of ICT on Quality of Working; Korunka, C., Hoonakker, P., Eds.; Springer: New-York, NY, USA, 2014; pp. 123-141.

15. Mark, G.; Su, N. Making infrastructure visible for nomadic work. Pervasive. Mob. Comput. 2010, 6, 312-323. [CrossRef]

16. De Carvalho, A.; Ciolfi, L.; Gray, B. The making of nomadic work: Understanding the mediational role of ICTs. In The Handbook of Research on Mobility and Computing: Evolving Technologies and Ubiquitous Impacts; Cruz-Cunha, M., Moreira, F., Eds.; IGI Global: Hershey, PA, USA, 2011; pp. 381-396.

17. Nash, E.; Jarrahi, M.; Sutherland, W. Nomadic work and location independence: The role of space in shaping the work of digital nomads. Hum. Behav. Emerg. Technol. 2020, 3, 271-282. [CrossRef]

18. Karaşar, B.; Öğülmüş, S. Investigation of the Validity and Reliability of the Need for Social Approval Scale on Adolescents. Anadolu J. Educ. Sciences Int. 2020, 10, 871-886. [CrossRef]

19. Hebert, J.; Ma, Y.; Clemow, L.; Ockene, I.; Saperia, G.; Stanek, E.; Merriam, P.; Ockene, J. Gender Differences in Social Desirability and Social Approval Bias in Dietary Self-report. Am. J. Epidemiol. 1997, 146, 1046-1055. [CrossRef] [PubMed]

20. Golden, T. Applying technology to work: Toward a better understanding of telework. Organ. Manag. J. 2009, 6, 241-250. [CrossRef]

21. Brun, J.-P.; Dugas, N. An analysis of employee recognition: Perspectives on human resources practices. Int. J. Hum. Resour. Manag. 2008, 19, 716-730. [CrossRef]

22. De Vries, H.; Tummers, L.; Bekkers, V. The Benefits of Teleworking in the Public Sector: Reality or Rhetoric? Rev. Public Pers. Adm. 2018, 39, 570-593. [CrossRef]

23. Scott, D.; Dam, I.; Páez, A.; Wilton, R. Investigating the Effects of Social Influence on the Choice to Telework. Environ. Plan. A. 2012, 44, 1016-1031. [CrossRef]

24. Hunton, J.; Norman, C. The Impact of Alternative Telework Arrangements on Organizational Commitment: Insights from a Longitudinal Field Experiment (Retracted). J. Inf. Syst. 2010, 24, 67-90. [CrossRef]

25. Taskin, L.; Edwards, P. The possibilities and limits of telework in a bureaucratic environment: Lessons from the public sector. New Technol. Work Employ. 2007, 22, 195-207. [CrossRef]

26. Greer, T.; Payne, S. Overcoming telework challenges: Outcomes of successful telework strategies. Psychol. Manag. J. 2014, 17, 87-111. [CrossRef]

27. Brown, S.; Massey, A.; Montoya-weiss, M.; Burkman, J. Do I really have to? User acceptance of mandated technology. Eur. J. Inf. Syst. 2002, 11, 283-295. [CrossRef]

28. Lee Mee Choo, J.; Mat Desa, N.; Asaari, M. Flexible working arrangement towards organizational commitment and work-family conflict. Stud. Asian Soc. Sci. 2016, 3, 21-36. [CrossRef]

29. Leslie, L.; Manchester, C.; Park, T.; Mehng, S. Flexible Work Practices: A Source of Career Premiums or Penalties? Acad. Manag. J. 2012, 55, 1407-1428. [CrossRef]

30. Grawitch, M.; Gottschalk, M.; Munz, D. The path to a healthy workplace: A critical review linking healthy workplace practices, employee well-being, and organizational improvements. Consult. Psychol. J. 2006, 58, 129-147. [CrossRef] 
31. Feys, M.; Anseel, F.; Wille, B. Responses to co-workers receiving recognition at work. J. Manag. Psychol. 2013, 28, 492-510. [CrossRef]

32. Deogaonkar, A. Emerging Technologies and Impact on Employee Relations. Int. J. Sci. Res. Publ. 2013, 3, 1-2.

33. Hislop, D.; Axtell, C. The neglect of spatial mobility in contemporary studies of work: The case of telework. New Technol. Work. Employ. 2007, 22, 34-51. [CrossRef]

34. Jalagat, R.; Jalagat, A. Rationalizing Remote Working Concept and Its Implications on Employee Productivity. Glob. J. Adv. Res. 2019, 6, 95-100.

35. Jones, K. Going Home: New Technology's Impact on Remote Work Engagement. Adv. Bus. Res. 2010, 1, $168-175$.

36. Konradt, U.; Schmook, R.; Wilm, A.; Hertel, G. Health circles for teleworkers: Selective results on stress, strain and coping styles. Health Educ. Res. 2000, 15, 327-338. [CrossRef]

37. Hilbrecht, M.; Shaw, S.; Johnson, L.; Andrey, J. 'I'm Home for the Kids': Contradictory Implications for Work-Life Balance of Teleworking Mothers. Gend. Work. Organ. 2008, 15, 454-476. [CrossRef]

38. Maruyama, T.; Hopkinson, P.; James, P. A multivariate analysis of work-life balance outcomes from a large-scale telework programme. New Technol., Work. Employ. 2009, 24, 76-88. [CrossRef]

39. Barnett, K.; Spoehr, J.; Moretti, C.; Gregory, T.; Chiveralls, K. Technology at Work-Stress, Work and Technology across the Lifecycle. Aust. Inst. Soc. Res. 2011. Available online: https://digital.library.adelaide.edu.au/dspace/bitstream/2440/122980/1/ Barnett_Technology_P2011.pdf (accessed on 1 November 2021).

40. Hilbrecht, M.; Shaw, S.; Johnson, L.; Andrey, J. Remixing work, family and leisure: Teleworkers' experiences of everyday life. New Technol. Work. Employ. 2013, 28, 130-144. [CrossRef]

41. Vayre, E.; Pignault, A. A Systemic Approach to Interpersonal Relationships and Activities among French Teleworkers. New Technol. Work Employ. 2014, 29, 177-192. [CrossRef]

42. Field, J.; Chan, X. Contemporary knowledge workers and the boundaryless work-life interface: Implications for the human resource management of the knowledge workforce. Front. Psychol. 2018, 9, 2414. [CrossRef]

43. Gálvez, A.; Martínez, M.J.; Pérez, C. Telework and work-life balance: Some dimensions for organisational change. J. Workplace Rights 2012, 16, 273-297. [CrossRef]

44. Derks, D.; Bakker, A. The Impact of E-mail Communication on Organizational Life. Cyberpsychology 2010, 4, 1.

45. Coovert, M.; Thompson, L. The Psychology of Workplace Technology; Routledge: London, UK, 2014.

46. Nisafani, A.S.; Kiely, G.; Mahony, C. Workers' technostress: A review of its causes, strains, inhibitors, and impacts. J. Decis. Syst. 2020, 1-16. [CrossRef]

47. Montreuil, S.; Lippel, K. Telework and occupational health: A Quebec empirical study and regulatory implications. Saf. Sci. 2003, 41, 339-358. [CrossRef]

48. Tavares, A. Telework and health effects review. Int. J. Healthc. 2017, 3, 30-36. [CrossRef]

49. Wyrzykowska, B. Telework and personnel risk. Sci. J. War.Univ. Life Sci. 2014, 14, 215-225.

50. Li, L.; Lin, T. Smartphones at Work: A Qualitative Exploration of Psychological Antecedents and Impacts of Work-Related Smartphone Dependency. Int. J. Qual. Methods 2019, 18, 1609406918822240. [CrossRef]

51. Spagnoli, P.; Molino, M.; Molinaro, D.; Giancaspro, M.L.; Manuti, L.; Ghislieri, C. Workaholism and Technostress during the COVID-19 Emergency: The Crucial Role of the Leaders on Remote Working. Front. Psychol. 2020, 11, 620310. [CrossRef]

52. Thulin, E.; Vilhelmson, B.; Johansson, M. New Telework, Time Pressure, and Time Use Control in Everyday Life. Sustainability 2019, 11, 3067. [CrossRef]

53. Ravalet, E.; Rérat, P. Teleworking: Decreasing Mobility or Increasing Tolerance of Commuting Distances? Built Environ. 2019, 45, 582-602. [CrossRef]

54. Hannonen, O. In search of a digital nomad: Defining the phenomenon. Inf. Technol. Tour. 2020, 22, 335-353. [CrossRef]

55. Pouchard, D.; Patte, F.; Lagabrielle, C.; Vonthron, A.-M. L'engagement en Formation: Rapport de Recherche; Publications AFPA: Montreuil, France, 2006.

56. Stinglhamber, F.; Vandenberghe, C. L'engagement envers l'organisation et le supérieur: Un examen de leurs antécédents. Psychol. Trav. Organ. 2002, 8, 137-165.

57. Meyer, J.; Allen, N. A three-component conceptualization of organizational commitment. Hum. Resour. Manag. Rev. 1991, 1, 61-89. [CrossRef]

58. Fall, A. Reconnaissance au travail: Validation d'une échelle de mesure dans le contexte des entreprises. Eur. Rev. Appl. Psychol. 2013, 65, 189-203. [CrossRef]

59. Brun, J.P.; Dugas, N. La reconnaissance au travail: Analyse d'un concept riche de sens. Gestion 2005, 30, 79-88. [CrossRef]

60. Geurts, S. SWING: Survey Work-Home Interaction-Nijmegen (Internal Research Report); University of Nijmegen: Nijmegen, The Netherlands, 2000.

61. Lourel, M.; Gana, K.; Wawrzyniak, S. L'interface "vie privée-vie au travail": Adaptation et validation française de l'échelle SWING (survey work-home interaction-Nijmegen). Psychol. Trav. Organ. 2005, 11, 227-239. [CrossRef]

62. Meerkerk, G.; Van Den Eijnden, R.; Vermulst, A.; Garretsen, H. The Compulsive Internet Use Scale (CIUS): Some psychometric properties. CyberPsychol. Behav. 2009, 12, 717-721. [CrossRef]

63. Khazaal, Y.; Chatton, A.; Horn, A.; Achab, S.; Thorens, G.; Zullino, D.; Billieux, J. French Validation of the Compulsive Internet Use Scale (CIUS). Psychiatr. Q. 2012, 83, 397-405. [CrossRef] 
64. Schaufeli, W.; Shimazu, A.; Taris, T. Being driven to work excessively hard: The evaluation of a two-factor measure of workaholism in the Netherlands and Japan. Cross Cult. Res. 2009, 43, 320-348. [CrossRef]

65. Sandrin, E.; Gillet, N. Validation d'une version française de la Dutch Work Addiction Scale (DUWAS). Psychol. Trav. Organ. 2016, 22, 147-159. [CrossRef]

66. Schaufeli, W.; Taris, T.; Van Rhenen, W. Workaholism, burnout, and work engagement: Three of kind or three different kinds of employee well-being? Appl. Psychol. 2008, 57, 173-203. [CrossRef]

67. Naderifar, M.; Goli, H.; Ghaljaie, F. Snowball Sampling: A Purposeful Method of Sampling in Qualitative Research. Stri. Dev. Medic. Educ. 2017, 14, 1-6. [CrossRef]

68. Mohamad, M.M.; Sulaiman, N.L.; Sern, L.C.; Salleh, K.M. Measuring the Validity and Reliability of Research Instruments. Procedia Soc. Behav. Sci. 2015, 204, 164-171. [CrossRef]

69. Wright, K.; Abendschein, B.; Wombacher, K.; O'Connor, M.; Hoffman, M.; Dempsey, M.; Krull, C.; Dewes, A.; Shelton, A. Work-Related Communication Technology Use Outside of Regular Work Hours and Work Life Conflict. Manag. Commun. Q. 2014, 28, 507-530. [CrossRef]

70. Chesley, N. Information and communication technology use, work intensification and employee strain and distress. Work Employ. Soc. 2014, 28, 589-610. [CrossRef]

71. Ninaus, K.; Diehl, S.; Terlutter, R.; Chan, K.; Huang, A. Benefits and stressors-Perceived effects of ICT use on employee health and work stress: An exploratory study from Austria and Hong Kong. Int. J. Qual. Stud. Health Well Being 2015, $10,28838$. [CrossRef] [PubMed]

72. Wheatley, D. Good to be home? Time-use and satisfaction levels among home-based teleworkers. New Technol. Work Employ. 2012, 27, 224-241. [CrossRef]

73. Uresha, I. Influence of Telecommuting on Work-life Balance and Employee Happiness: An Empirical Study of Sri Lankan Employees. Int. J. Manag. Excell. 2020, 15, 2234-2243.

74. Schmoll, R.; Süß, S. Working Anywhere, Anytime: An Experimental Investigation of Workplace Flexibility's Influence on Organizational Attraction. Manag. Rev. 2019, 30, 40-62. [CrossRef]

75. Griffiths, M. Internet gambling: Issues, concerns and recommendations. Cyberpsychol. Behav. 2003, 6, 557-570. [CrossRef]

76. Harwood, J.; Dooley, J.J.; Scott, A.J.; Joiner, R. Constantly connected-the effects of smart-devices on mental health. Comput. Hum. Behav. 2014, 34, 267-272. [CrossRef]

77. Rafiei, M.; Taghi Amini, M.; Foroozandeh, N. Studying the impact of the organizational commitment on the job performance. Manag. Sci. Lett. 2014, 4, 1841-1848. [CrossRef]

78. Nadesan, T. Relationship between Work-Life Balance and Job Performance of Employees. IOSR J. Bus. Manag. 2008, 20, 11-16.

79. Sungu, L.-J.; Weng, Q.; Xu, X. Organizational commitment and job performance: Examining the moderating roles of occupational commitment and transformational leadership. Int. J. Sel. Assess. 2019, 27, 280-290. [CrossRef]

80. Hussain, S.; Khaliq, D.; Nisar, Q.; Kamboh, A.; Ali, S. The Impact of Employees' Recognition, Rewards and Job Stress on Job Performance: Mediating Role of Perceived Organization Support. SEISENSE J. Manag. 2019, 2, 69-82. [CrossRef]

81. Secunda, P. The Employee Right to Disconnect. Notre Dame J. Int. Comp. Law 2018, 9, 1-41.

82. Westerman, G.; Bonnett, D.; McAffee, A. Gagner Avec le digital; Diateino: Paris, France, 2014.

83. Verhoef, P.; Broekhuizen, T.; Bart, Y.; Bhattacharya, A.; Qi Dong, J.; Fabian, N.; Haenlein, M. Digital transformation: A multidisciplinary reflection and research agenda. J. Bus. Res. 2019, 122, 889-901. [CrossRef]

84. Fenner, G.; Renn, R. Technology-assisted supplemental work and work-to-family conflict: The role of instrumentality beliefs, organizational expectations and time management. Hum. Relat. 2010, 63, 63-82. [CrossRef]

85. Matusik, S.; Mickel, A. Embracing or embattled by converged mobile devices? Users' experiences with a contemporary connectivity technology. Hum. Relat. 2011, 64, 1001-1030. [CrossRef]

86. Derks, D.; Van Duin, D.; Tims, M.; Bakker, A. Smartphone use and work-home interference: The moderating role of social norms and employee engagement. J. Occup. Organ. Psychol. 2015, 88, 155-177. [CrossRef] 